\title{
Biogenic, sedimentary, and metamorphic limestone: a comparative characterization of soil amendments ${ }^{1}$
}

\author{
Maria Maiara Cazotti ${ }^{*}$ (D), Liovando Marciano da Costa ${ }^{2}$, Paulo Roberto Cecon ${ }^{3}$
}

10.1590/0034-737X201966010009

\begin{abstract}
Liming acid soils is fundamental for agricultural activity such as the study and characterization of alternative liming materials. The objective of this study was to characterize biological, sedimentary, and metamorphic limestones. The following limestones were studied: biogenic (BL), sedimentary (SL), commercial (CL), and marble (ML). This study evaluated total relative neutralizing power (TRNP), chemical composition, specific surface area, and $\mathrm{Ca}^{2+}$ and $\mathrm{Mg}^{2+}$ release at concentrations of $0.10,0.50,1.00$, and $2.00 \mathrm{~mol} \mathrm{~L}^{-1} \mathrm{HCl}$, in addition to the effects on the soil 90 days after limestone application. The Si identified contributed to the lower TRNP of BL (73.7\%) and CL (74.4\%). At the lowest $\mathrm{HCl}$ concentrations, BL was the most reactive, but with an increase in concentration, ML became the most reactive. The highest $\mathrm{CaO}$ (58.32\%) and $\mathrm{MgO}$ (13.05\%) levels were observed in SL and ML, respectively, which contained the highest $\mathrm{Ca}^{2+}\left(3.95 \mathrm{cmol}_{\mathrm{c}} \mathrm{dm}^{-3}\right)$ and $\mathrm{Mg}^{2+}\left(1.09 \mathrm{cmol}_{\mathrm{c}} \mathrm{dm}^{-3}\right)$ concentrations when applied to the soil. All the limestones increased $\mathrm{pH}$ and lowered soil $\mathrm{H}+\mathrm{Al}$. Soil $\mathrm{Ca}^{2+}$ and $\mathrm{Mg}^{2+}$ were influenced by the composition of the amendments.
\end{abstract}

Keywords: liming; lithothamnium; soil acidity.

\section{RESUMO}

\section{Calcário biogênico, sedimentar e metamórfico: caracterização comparativa na correção de solos ${ }^{1}$}

A correção da acidez é fundamental para a atividade agrícola em solos ácidos, assim como a caracterização e estudo do efeito no solo de fontes alternativas de corretivos. Objetivou-se caracterizar os calcários de origem biológica, sedimentar e metamórfica. Os calcários estudados foram: biogênico (CB), sedimentar (CS), comercial (CC) e o mármore (CM). Foram avaliados: poder relativo de neutralização total (PRNT); composição química; área superficial específica e liberação de $\mathrm{Ca}^{2+} \mathrm{e} \mathrm{Mg}^{2+}$ nas concentrações de 0,10; 0,50; 1,00 e 2,00 mol L-1 de $\mathrm{HCl}$ e os efeitos no solo, após 90 dias da aplicação dos calcários. O Si identificado contribuiu para o menor PRNT do CB $(73,7 \%)$ e CC $(74,4 \%)$. Nas menores concentrações de $\mathrm{HCl}$, o CB mostrou-se mais reativo, porém com o aumento da concentração do $\mathrm{HCl}$, o CM passou a ser mais reativo. Os maiores teores de $\mathrm{CaO}(58,32 \%)$ e $\mathrm{MgO}(13,05 \%)$ foram observados no CS e CM, respectivamente,

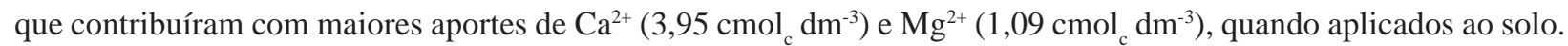

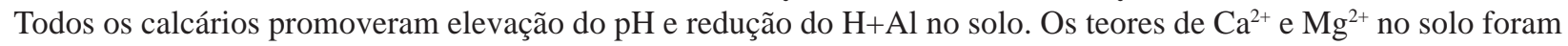
influenciados pela composição dos corretivos.

Palavras-chave: lithothamnium; calagem; acidez do solo.

\footnotetext{
Submitted on March 16 $6^{\text {th }}, 2018$ and accepted on December $3^{\text {rd }}, 2018$

' This paper is part of the first author's Master's dissertation.

${ }^{2}$ Universidade Federal de Viçosa, Departamento de Solos, Viçosa, Minas Gerais, Brazil. maiaracazotti@hotmail.com; liovando.costa@ufv.com

${ }^{3}$ Universidade Federal de Viçosa, Departamento de Estatística, Viçosa, Minas Gerais, Brazil. cecon@ufv.com

Corresponding author: maiaracazotti@hotmail.com
} 


\section{INTRODUCTION}

Acid soils present high saturation by $\mathrm{Al}$, low saturation by base, and lower availability of P (Fageria, 2011), all of which limit the development of most agricultural crops (Bortoluzzi et al., 2014; Singh et al., 2017). Liming stands out as an efficient and less costly practice to raise $\mathrm{pH}$, contents of $\mathrm{Ca}, \mathrm{Mg}$, base saturation, and $\mathrm{P}$ availability and to reduce toxic $\mathrm{Al}$ in soil (Fageria, 2011, Rheinheimer et al. 2018). These effects result in a significant improvement in the production capacity of the soils, which allows better yields to the farmer in addition to avoiding the opening of new areas (Crusciol et al., 2016; Inagaki et al., 2016).

Although studies on the field of acidity correction and improvement in soil fertility show great progress, there is a need to seek new agricultural inputs, which are sustainable and provide greater productivity. In this context, it is important to characterize and understand the behavior of non-conventional sources for acidity correction in the soil, such as marine biogenic limestone.

Limestone produced from the extraction of calcareous algae receives the name of marine biogenic limestone or lithothamnium, alluding to the genus of Lithothamnium algae, which are the most extracted ones. The group of calcareous algae presents over 30 genera and about 500 species (Dias, 2000). Marine biogenic limestone represents a renewable short-term source. According to Dias (2000) and Melo \& Moura (2009), as long as there is light, algae grow naturally in the marine environment up to approximately $200 \mathrm{~m}$ of depth. Since the seventeenth century, calcareous algae have been used for the correction of acid soils in Europe (Dias, 2000). However, in Brazil, its agricultural use and exploration are still incipient.

According to Alvarez et al. (1999), the reactivity of a limestone depends somewhat on its geological nature, in which those of sedimentary origin and of a less crystalline nature are more reactive than the metamorphic ones, with a more crystalline structure. Gallo \& Catani (1954) reported that sedimentary rocks are more soluble than metamorphic rocks of the same chemical composition. However, Bellingieri et al. (1989) reported that the efficiency of limestones in soil acidity correction is not influenced by their geological nature, provided they have the same particle size. Such information gives rise to a demand for knowledge on the performance of biogenic, sedimentary, and metamorphic limestone in agriculture.

Limestones of sedimentary origin are formed through the disintegration and decomposition of preexisting rocks by weathering agents, in which the $\mathrm{Ca}$ in solution is conducted to continental or marine accumulation sites. Evaporation and temperature variations can reduce the $\mathrm{CO}_{2}$ content in the water and precipitate $\mathrm{CaCO}_{3}$ due to saturation conditions (Sampaio \& Almeida, 2008). Metamorphic rocks, represented by marbles, can also be used as acidity correctives. Moreover, they are composed of calcite and/or dolomite and result from the recrystallization of limestone rocks, mostly of sedimentary nature by means of high temperatures and pressure (Sampaio \& Almeida, 2008).

The objective of this study was to comparatively characterize limestone of biological, sedimentary, and metamorphic origin for use in agriculture.

\section{MATERIAL AND METHODS}

The experiment was carried out in the Geochemistry Laboratory and in a greenhouse belonging to the Department of Soils in the Universidade Federal de Viçosa, Viçosa, MG - Brazil, from March to July 2014. The limestones used in the experiment were the following: marble (ML), biogenic limestone (BL), commercial limestone (CL), and sedimentary limestone (SL). Figure 1 shows the location of the municipalities from where the corrective samples were collected.

Blocks of the studied materials were collected in each location. In the laboratory, ML and SL were washed with distilled water, broken into smaller blocks with the aid of a geological hammer, and ground in a disc mill. After that, they were standardized in the particle size of less than 0.074 , for characterization and experiment assembly.

The total relative neutralizing power (TRNP) and the $\mathrm{CaO}$ and $\mathrm{MgO}$ contents were determined according to Mapa (2014), considering four replications. The determination of $\mathrm{Ca}^{2+}$ and $\mathrm{Mg}^{2+}$ elements was obtained using an atomic absorption spectrometer. Total contents of $\mathrm{Ca}$, $\mathrm{Mg}, \mathrm{Al}, \mathrm{K}, \mathrm{P}, \mathrm{Na}$, and $\mathrm{Si}$ contents were determined by the alkaline fusion method, following the procedure described by Pansu \& Gautheyrou (2003), adapted by Guerra et al. (2013). The dosage of the above elements was performed in inductively coupled plasma - optical emission spectrometry (ICP-OES). The B.E.T. method was used to determine the specific surface area (SSA). (Brunauer, Emmett and Teller) using the NOVA instrument (Quantachrome Instruments version 10.01) (Gregg \& Sing, 1982).

Regarding the solubility test in hydrochloric acid, the methodology adapted from Amaral Sobrinho et al. (1992) was used, which consists of weighing $1 \mathrm{~g}$ of limestone in 125-mL Erlenmeyer. Then, $50 \mathrm{~mL} \mathrm{HCl}$ was added at the concentrations of $0.01,0.10,0.50,1.00$, and $2.00 \mathrm{~mol} \mathrm{~L}^{-1}$, with four replicates. The reaction time was $12 \mathrm{~h}$, in which the samples were shaken for 15 min every hour in a shaker of 200 oscillations per minute. After the reaction period, the solutions containing limestone samples were filtered on slow filtering quantitative filter paper. Then, contents of the $\mathrm{Ca}^{2+}$ and $\mathrm{Mg}^{2+}$ were determined in the filtrate by 
atomic absorption spectroscopy. The filter papers containing the residues were taken to the muffle at $500{ }^{\circ} \mathrm{C}$ for $1 \mathrm{~h}$. By mass difference before acid attack and post muffle, it was possible to determine the limestone residue for each sample.

An incubation experiment was carried out, by using samples of Red-Yellow Latosol (Embrapa, 2018), collected in the city of Viçosa, MG, in the $0-20 \mathrm{~cm}$ layer. The results of the soil chemical analysis were as follows: $\mathrm{pH}\left(\mathrm{H}_{2} \mathrm{O}\right)$, 5.24; $\mathrm{Al}^{3+}\left(\mathrm{cmol}_{\mathrm{c}} \mathrm{dm}^{-3}\right), 1.4 ; \mathrm{H}+\mathrm{Al}^{3+}\left(\mathrm{cmol}_{\mathrm{c}} \mathrm{dm}^{-3}\right), 9.70 ; \mathrm{Ca}^{2+}$ $\left(\mathrm{cmol}_{\mathrm{c}} \mathrm{dm}^{-3}\right), 0.63 ; \mathrm{Mg}^{+2}\left(\mathrm{cmol}_{\mathrm{c}} \mathrm{dm}^{-3}\right), 0.14 ; \mathrm{K}^{+}\left(\mathrm{mg} \mathrm{dm}^{-3}\right)$, 43.00; $\mathrm{P}\left(\mathrm{mg} \mathrm{dm}^{-3}\right), 1.2$. The physical characterization indicated sand, silt, and clay contents of 130, 190, and 680 $\mathrm{g} \mathrm{kg}^{-1}$, respectively. The methods used in these analyzes are described by Embrapa (2011). Based on the results of chemical analysis of soil and limestone, the need for liming (NL) was determined for the soil, using the $\mathrm{Al}^{3+}$ neutralization method and raising of contents of $\mathrm{Ca}^{2+}$ and $\mathrm{Mg}^{2+}$ (Alvarez et al., 1999). For the purpose of calculating the NL, the parameters of the corn crop were considered. To calculate the amount of limestone to be applied, the TRNP found for the different materials studied was considered.
The limestones were applied to the dry soil and homogenized throughout the volume. The treatments, arranged in a factorial scheme $(4 \times 4)+1$, consisted of four acidity limestones (ML, BL, CL, and SL), four NL levels (30,60, 100 and 150\%), and one control, with no limestone application, and were distributed in randomized blocks, with three replications. Each experimental unit consisted of a plastic bag, with a capacity of $1 \mathrm{dm}^{3}$ of soil, distributed on a bench, inside the greenhouse. The experimental units were maintained with humidity between 60 and $80 \%$ of the field capacity, through weighing and replenishment of water. The plastic bags were kept slightly open, using polypropylene tubes, to allow gas exchanges.

The sample units were incubated for 90 days. At the end of the incubation period, the fine air-dry soil of each experimental unit was obtained. From the fine air-dry soil, the following chemical and physical-chemical features were determined: $\mathrm{pH}$ in water, in the 1:2.5 soil:solution ratio; $\mathrm{Ca}^{2+}$ and $\mathrm{Mg}^{2+}$ contents (extraction with $\mathrm{KCl} 1 \mathrm{~mol}$ $\mathrm{L}^{-1}$ ); exchangeable acidity by titration (extraction with $\mathrm{KCl}$ $1 \mathrm{~mol} \mathrm{~L}^{-1}$ ); and potential acidity, also by titration (extraction with $\mathrm{Ca}(\mathrm{Ac})_{2} 0.5 \mathrm{~mol} \mathrm{~L}^{-1}$ at $\mathrm{pH} 7,1: 15$ soil:solution ratio) (Embrapa, 2011).

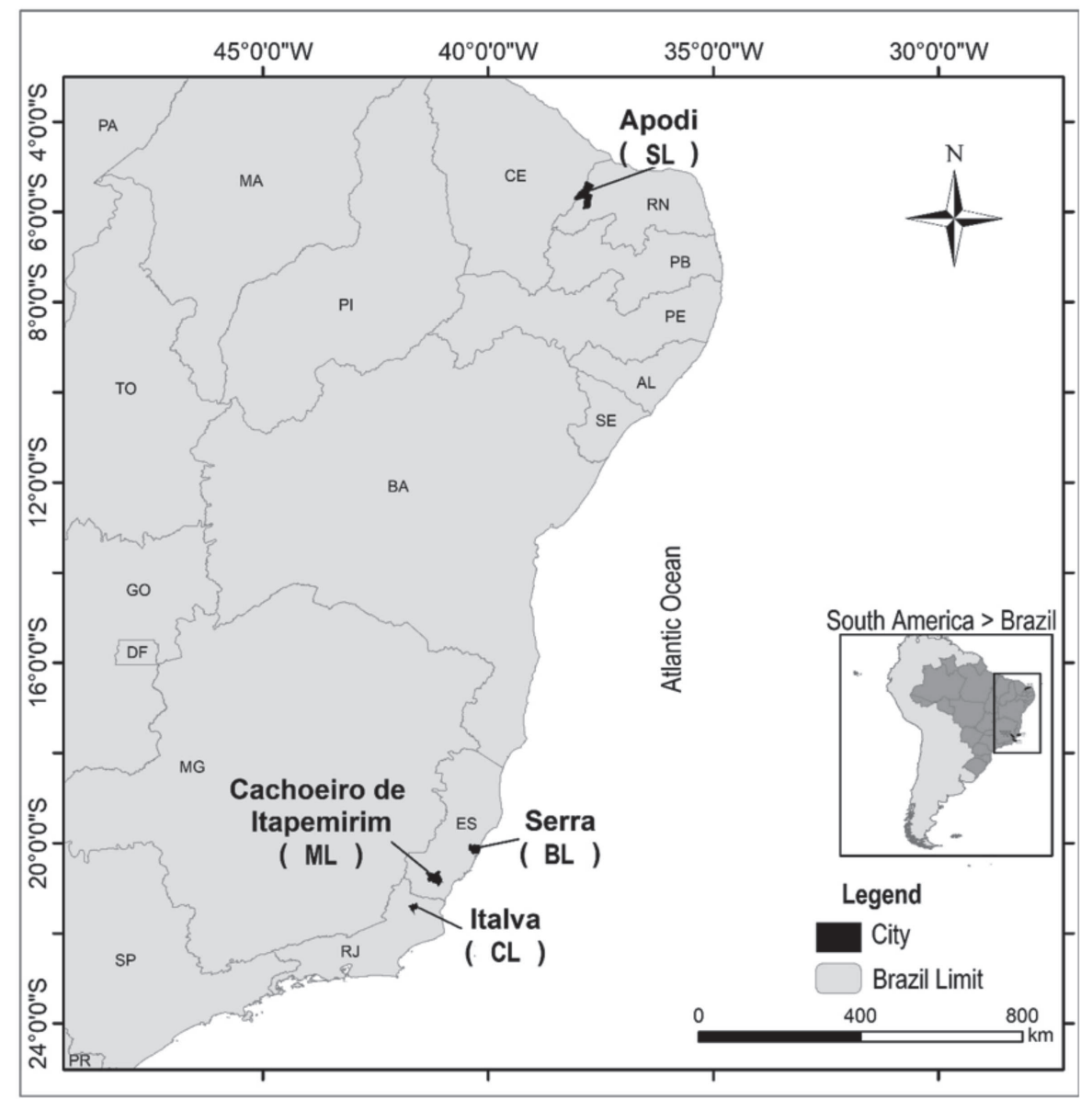

Figure 1: Location of the collection area of the different correctives. ML: metamorphic limestone; BL: biogenic limestone; CL: commercial limestone; and SL: sedimentary limestone. 
The means obtained for $100 \%$ of the NL at the agronomic interest level were compared by the classification proposed by the Fifth Approximation Recommendation of Corrective and Fertilizers (Ribeiro et al., 1999) to relate the results experimentally obtained for the different limestones with those targeted in the agricultural practices.

Data were subjected to analysis of variance. In relation to the qualitative factor, the means were compared using the Tukey test, adopting the $5 \%$ probability level. To compare the control to the other treatments, Dunnett's test was used, adopting the $5 \%$ probability level. For the quantitative factor, regressions were adjusted, and the models were chosen based on the significance of the regression coefficients using the $t$ test at the $1 \%$ probability level, in the coefficient of determination $\left(\mathrm{R}^{2}=\right.$ S.S Regression/ S.S Treatment) and the behavior of the phenomenon under study. Because of the great variability, the descriptive statistical analysis was chosen for the chemical characterization of the different acidity correctives under study. SAEG 9.1 was used to support the statistical analysis (Universidade Federal de Viçosa, 2007).

\section{RESULTS AND DISCUSSION}

In the chemical limestone characterization (Table 1), except for $\mathrm{Ca}$ and $\mathrm{Mg}$, the highest concentrations of $\mathrm{Al}$, $\mathrm{Na}, \mathrm{Zn}, \mathrm{Fe}, \mathrm{Cu}, \mathrm{Mn}, \mathrm{B}, \mathrm{K}, \mathrm{P}$, and Si elements were observed in BL (Table 1). According to Melo \& Moura (2009), the main characteristics that potentiate calcareous algae are attributed to the greater availability of micronutrients, adsorbed on cell walls, easily assimilated by plants and animals. In addition, Dias (2000) indicated that calcareous algae are composed mainly of $\mathrm{CaCO}_{3}$ and $\mathrm{MgCO}_{3}$ and varying concentrations of elements such as $\mathrm{Fe}, \mathrm{Mn}, \mathrm{B}$, $\mathrm{Ni}, \mathrm{Cu}, \mathrm{Zn}, \mathrm{Mo}, \mathrm{Se}$, and $\mathrm{Sr}$.
A larger concentration of $\mathrm{Mg}$ and $\mathrm{Ca}$ was observed in $\mathrm{CM}$ and in SL, respectively, due to the inherent characteristics of each reserve. Jordt-Evangelista \& Viana (2000) observed that the marbles that compose the collection region of the ML are predominantly composed of dolomite, with small intrusions of calcite, whereas limestones with low dolomite content compose the collection SL region.

Due to the particle size standardization in a sieve smaller than $0.074 \mathrm{~mm}$, the TRNP will be equal to the NP (neutralization power). The limestone NP was: $\mathrm{ML}=98.9 \%$; $\mathrm{BL}=73.7 \% ; \mathrm{CL}=74.4 \%$; and $\mathrm{SL}=96.3 \%$. The lowest NP values were observed in the BL and CL, a fact that may be associated with the presence of silicate minerals in the composition of the correctives. In the chemical characterization, 65.72 and $57.19 \mathrm{mg} \mathrm{g}^{-1}$ Si were observed in BL and CL correctives, respectively. The neutralizing capacity of limestones considers the chemical purity of the rock of origin and the fineness of grinding (Quaggio, 2000). For the same granulometry, the higher the chemical purity of the rock, the higher the TRNP of the corrective.

The $\mathrm{CaO}$ and $\mathrm{MgO}$ contents maintained the same behavior of the total contents of $\mathrm{Ca}$ and $\mathrm{Mg}$ in the correctives. The $\mathrm{CaO}$ and $\mathrm{MgO}$ contents were as follows: ML with $35.40 \% \mathrm{CaO}$ and $13.05 \% \mathrm{MgO}$; BL with $43.90 \%$ $\mathrm{CaO}$ and $2.91 \mathrm{MgO}$; $\mathrm{CL}$ with $30.80 \% \mathrm{CaO}$ and $6.63 \% \mathrm{MgO}$; and SL with $58.32 \% \mathrm{CaO}$ and $0.51 \% \mathrm{MgO}$.

The largest SSA was observed in BL, with a value of $4.05 \mathrm{~m}^{2} \mathrm{~g}^{-1}$. According to Melo \& Moura (2009), calcareous algae present high porosity that provides a greater surface area of action. The ML, CL, and SL presented SSA of 0.09, 1.68 , and $2.08 \mathrm{~m}^{2} \mathrm{~g}^{-1}$, respectively. The smaller SSA observed in the ML and CL may be attributed to the higher crystallinity of these rocks.

According to Gonçalves et al. (2011) and Rodrighero et al. (2015), neutralization speed depends on the surface

Table 1: Average contents and standard deviations of the contents of $\mathrm{Al}, \mathrm{Ca}, \mathrm{K}, \mathrm{Mg}, \mathrm{Na}, \mathrm{P}, \mathrm{Fe}, \mathrm{Zn}, \mathrm{Cu}, \mathrm{Mn}, \mathrm{B}$, and $\mathrm{Si}$ in the different acidity correctives

\begin{tabular}{|c|c|c|c|c|c|c|}
\hline \multirow{2}{*}{$\begin{array}{l}\text { Acidity } \\
\text { correctives }\end{array}$} & Al & $\mathbf{C a}$ & Mg & $\mathbf{N a}$ & Zn & $\mathbf{F e}$ \\
\hline & \multicolumn{6}{|c|}{$\mathrm{mg} \mathrm{g}^{-1}$} \\
\hline $\mathrm{ML}$ & $0.614 \pm 0.022$ & $262.694 \pm 5.305$ & $179.238 \pm 3.920$ & $0.116 \pm 0.006$ & $0.009 \pm 0.001$ & $0.375 \pm 0.042$ \\
\hline BL & $10.541 \pm 0.833$ & $283.143 \pm 7.760$ & $29.960 \pm 1.001$ & $2.870 \pm 0.042$ & $0.013 \pm 0.001$ & $11.489 \pm 0.235$ \\
\hline CL & $5.624 \pm 0.472$ & $274.192 \pm 3.299$ & $115.018 \pm 3.274$ & $0.119 \pm 0.001$ & $0.012 \pm 0.0001$ & $2.004 \pm 0.006$ \\
\hline \multirow[t]{3}{*}{ SL } & $2.688 \pm 0.787$ & $403.464 \pm 7.063$ & $7.406 \pm 0.575$ & $0.097 \pm 0.006$ & $0.007 \pm 0.0001$ & $1.424 \pm 0.036$ \\
\hline & $\mathrm{Cu}$ & Mn & B & $\mathbf{K}$ & $\mathbf{P}$ & Si \\
\hline & \multicolumn{6}{|c|}{$\mathrm{mg} \mathrm{g}^{-1}$} \\
\hline $\mathrm{ML}$ & $0.006 \pm 0.0001$ & $0.008 \pm 0.001$ & $0.004 \pm 0.0001$ & $4.778 \pm 0.898$ & $1.406 \pm 0.009$ & $11.702 \pm 0.312$ \\
\hline BL & $0.006 \pm 0.0001$ & $0.379 \pm 0.005$ & $0.012 \pm 0.0001$ & $4.158 \pm 0.386$ & $1.786 \pm 0.093$ & $65.718 \pm 6.890$ \\
\hline $\mathrm{CL}$ & $0.008 \pm 0.0001$ & $0.064 \pm 0.0001$ & $0.005 \pm 0.0001$ & $3.544 \pm 0.487$ & $<\mathrm{LD}$ & $57.187 \pm 1.361$ \\
\hline SL & $0.008 \pm 0.0001$ & $0.046 \pm 0.001$ & $0.004 \pm 0.0001$ & $1.773 \pm 0.089$ & $<\mathrm{LD}$ & $10.044 \pm 0.496$ \\
\hline
\end{tabular}

$<\mathrm{LD}=$ below the gadget detection limit.

Rev. Ceres, Viçosa, v. 66, n.1, p. 063-071, jan/fev, 2019 
area of the corrective in contact with the soil and, due to the low solubility of the limestones, it requires its incorporation in the soil to promote a better reaction (Alleoni et al., 2005). Acidity correctives with a large contact surface may present great potential in areas where limestone has not been incorporated such as in the notillage system. According to Alleoni et al. (2005), in the no-tillage system, as time passes by, the intervention with limestone application is necessary because there is a decrease in $\mathrm{pH}$ and, consequently, an increase in $\mathrm{Al}^{3+}$ on the superficial layer. In these cases, the use of limestones with higher reaction velocity associated with greater residual power becomes interesting. In this way, BL could be used combined with other limestones with a smaller contact surface to reduce the reaction time and to increase the residual effect.

\section{Solubility of the different limestones in hydrochloric acid}

Among the evaluated limestones (Table 2), BL was more reactive at the concentrations of 0.01 and $0.1 \mathrm{~mol} \mathrm{~L}^{-1} \mathrm{HCl}$; however, as the $\mathrm{HCl}$ concentration was increased, the carbonate consumption occurred, providing greater residue generation in $\mathrm{BL}$ as well as in CL treatments as both limestones presented the lowest NP values among them. The ML and SL presented higher chemical purity, consequently, higher NP values and a smaller amount of residue.

By using the adjusted equation of the variable limestone residue as a function of the concentration (Figure $2 \mathrm{~A}$ ), it was observed that concentrations greater than $0.31 \mathrm{~mol} \mathrm{~L}^{-1} \mathrm{HCl}$ solubilize the carbonates present in BL. In CL, values greater than $0.29 \mathrm{~mol} \mathrm{~L}^{-1} \mathrm{HCl}$ were obtained, that is, from those concentrations, the concentration does not affect the generation of limestone residue anymore. A likely influence of the specific surface area was observed in ML and SL. In SL, the surface area is 30 times larger than in ML, with a faster consumption of carbonates. On the other hand, because ML is a more crystalline rock and, consequently, presents a smaller SSA, $\mathrm{HCl}$ found greater difficulty to solubilize the carbonates. The lower solubility of ML may also be related to its chemical constitution; when a change occurs in the crystalline structure of limestones, through the substitution of $\mathrm{Ca}$ ions with $\mathrm{Mg}$ ions, the solubility of limestones decreases (Grunwaldt et al., 2016). Rodrighero et al. (2015) observed that the solubility of limestones containing a large $\mathrm{Ca}$ content was higher than that of dolomitic limestones with the same particle size.

In relation to $\mathrm{Ca}^{2+}$ release, it was observed that at the concentration of $0.01 \mathrm{~mol} \mathrm{~L}^{-1}$, the correctives ML, CL, and SL presented a greater release of $\mathrm{Ca}^{2+}$ in relation to $\mathrm{BL}$; at the concentration of $0.10 \mathrm{~mol} \mathrm{~L}^{-1} \mathrm{HCl}$, the limestones that

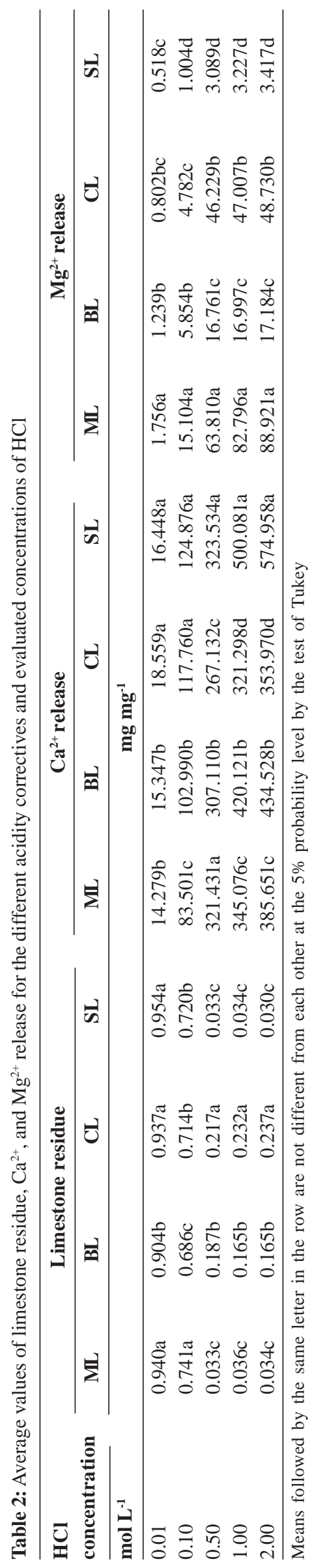

Rev. Ceres, Viçosa, v. 66, n.1, p. 063-071, jan/fev, 2019 
released more $\mathrm{Ca}^{2+}$ to the solution were CL and SL; and at the concentration of 0.50 , the limestones ML and SL stood out. Only at the 1.00 and $2.00 \mathrm{~mol} \mathrm{~L}^{-1} \mathrm{HCl}$ concentrations, the $\mathrm{Ca}^{2+}$ release followed the same trend observed in the chemical characterization. The limestones presented $\mathrm{CaO}$ percentage and $\mathrm{Ca}^{2+}$ release in the following order: $\mathrm{SL}>$ $\mathrm{BL}>\mathrm{ML}>\mathrm{CL}$. In relation to the release of $\mathrm{Mg}^{2+}$, it followed the same trend observed in the chemical characterization, in which the limestones ML and CL presented the greatest percentages of $\mathrm{MgO}$ and greater release of $\mathrm{Mg}$ to the solution (Table 2).

For the adjusted values of $\mathrm{Ca}^{2+}$ release (Figure 2B), it was observed that as $\mathrm{HCl}$ concentration increased, a greater $\mathrm{Ca}^{2+}$ release occurred in limestones with higher $\mathrm{CaO}$, SL followed by BL. Similar behavior was observed for $\mathrm{Mg}^{2+}$ release when ML and CL also released more $\mathrm{Mg}^{2}$ ${ }^{+}$since they presented a higher percentage of $\mathrm{MgO}$ (Figure $2 \mathrm{C})$.

\section{Effects of limestones on soil physicochemical characteristics}

It was observed with the analysis of variance that only the levels of NL had a statistically significant influence on soil $\mathrm{pH}$ ( $\mathrm{p}<0.05$ ), whilst the variables $\mathrm{H}+\mathrm{Al}, \mathrm{Ca}^{2+}$ and $\mathrm{Mg}^{2+}$ were statistically influenced by the different sources of limestone and liming levels.

It was observed that the adjusted $\mathrm{pH}$ values as a function of NL increased linearly as the levels of NL increased (Figure 3A). Similar results were also observed by Kurihara et al. (1999), in which at the end of 100 days of incubation, the increase in $\mathrm{pH}$ was similar between sedimentary and metamorphic limestones with a particle size within the 50-70 mesh interval. The treatments that received acidity correctives showed significant $(\mathrm{p}<0.05)$ and greater results than the control by the Dunnett test (Table 3). The $\mathrm{pH}$ of the control was classified as low (4.55.4); however, regardless of the soil acidity corrective applied to the soil at the level of agronomic interest, the $\mathrm{pH}$ reached values classified as good (5.5-6.0), and at the level of $150 \%$ of liming requirement, it reached values classified as high (6.1-7.0).

In relation to the active acidity, ML and BL reduced $\mathrm{Al}^{3+}$ from $1.23 \mathrm{cmol}_{\mathrm{c}} \mathrm{dm}^{-3}$, observed in the control, to 0.48 $\mathrm{cmol}_{\mathrm{c}} \mathrm{dm}^{-3}$ at $30 \%$ of NL. The value observed when the CL and SL were applied was $0.58 \mathrm{cmol}_{\mathrm{c}} \mathrm{dm}^{-3}$. At $60 \%$ of NL, values of $\mathrm{Al}^{3+}$ observed with the application of the $\mathrm{BL}$
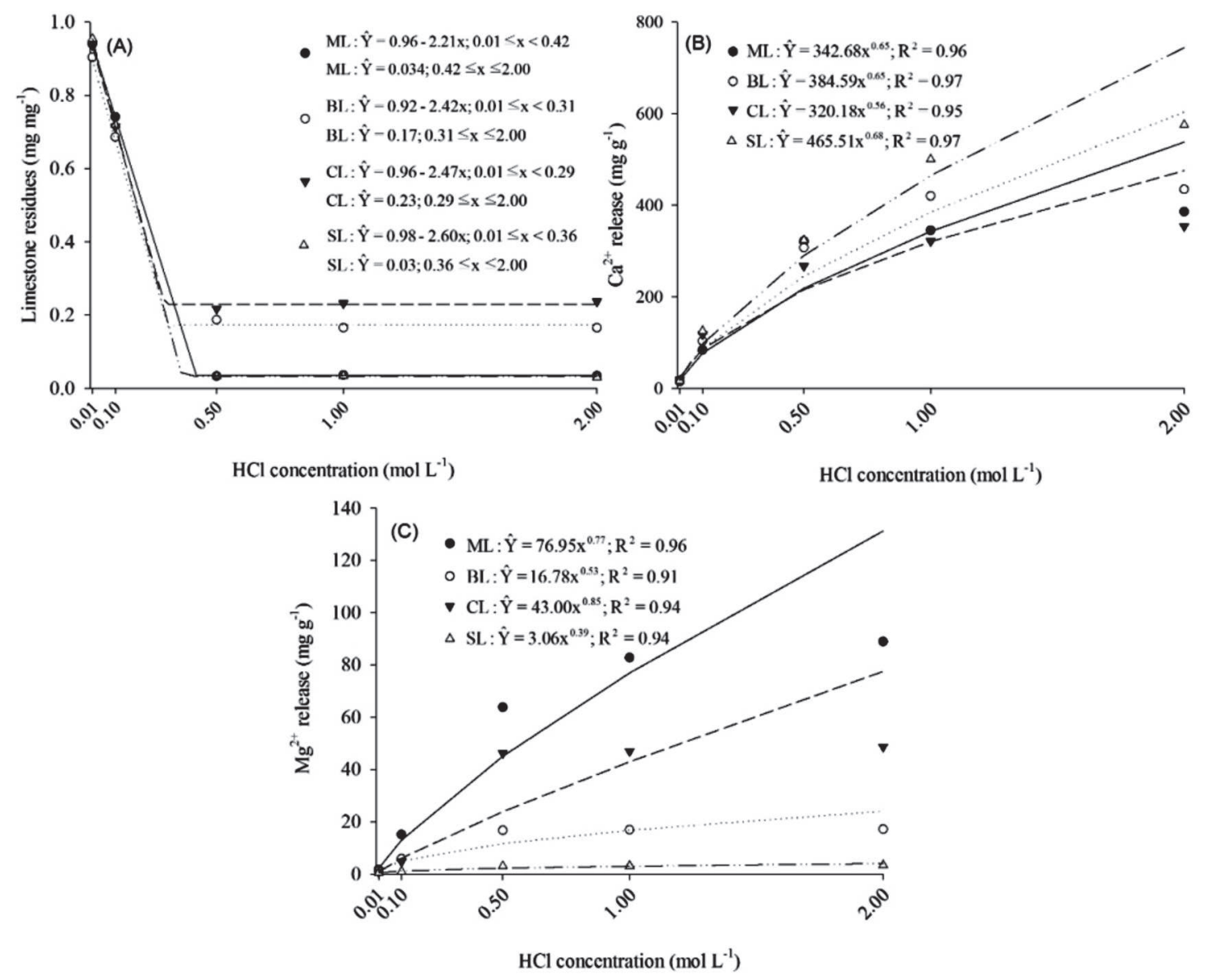

Figure 2: Values of the limestone residues, $\mathrm{Ca}^{2+}$, and $\mathrm{Mg}^{2+}$ release as a function of $\mathrm{HCl}$ concentration for the different acidity correctives.

Rev. Ceres, Viçosa, v. 66, n.1, p. 063-071, jan/fev, 2019 
and SL correctives were $0.10 \mathrm{cmol}_{\mathrm{c}} \mathrm{dm}^{-3}, \mathrm{ML}$ of $0.19 \mathrm{cmol}_{\mathrm{c}}$ $\mathrm{dm}^{-3}$, and CL of $0.29 \mathrm{cmol}_{\mathrm{c}} \mathrm{dm}^{-3}$. The $\mathrm{pH}$ range reached at 100 and $150 \%$ of liming requirement, regardless of the limestone applied, was sufficient to reduce $\mathrm{Al}^{3+}$ to zero. The exchangeable acidity has an inverse relationship with soil $\mathrm{pH}$; therefore, the rise in $\mathrm{pH}$ is one of the alternatives to reduce the toxic effect of Al (Sousa et al., 2007). According to the same authors, when the $\mathrm{pH}$ of the soil, determined in water, is close to $5.5, \mathrm{Al}^{3+}$ is reduced to almost zero.

The application of increasing levels of limestone promoted a reduction in values of $\mathrm{H}+\mathrm{Al}$ (Figure $3 \mathrm{~B}$ ). In relation to the behavior of the different limestones within each liming level (Table 3), at the $30 \%$ level, the BL acidity corrective presented the lowest average $\mathrm{H}+\mathrm{Al}$ values. At 60 and $100 \%$ levels, the lowest mean values were observed in ML-treated samples. At the $150 \%$ level, there was no statistical difference between limestones. Regardless of the evaluated limestone, at the liming level of agronomic interest, limestones were effective in reducing the potential acidity of the very high level presented in the control (> $\left.9.00 \mathrm{cmol} \mathrm{dm}_{\mathrm{c}}^{-3}\right)$ for values classified as medium (2.51-5.00 $\mathrm{cmol}_{\mathrm{c}} \mathrm{dm}^{-3}$ ). According to Dunnett's test, all treatments that received lime presented lower and statistically significant $\mathrm{H}+\mathrm{Al}$ values $(\mathrm{p}<0.05)$ compared with the control (Table 3).
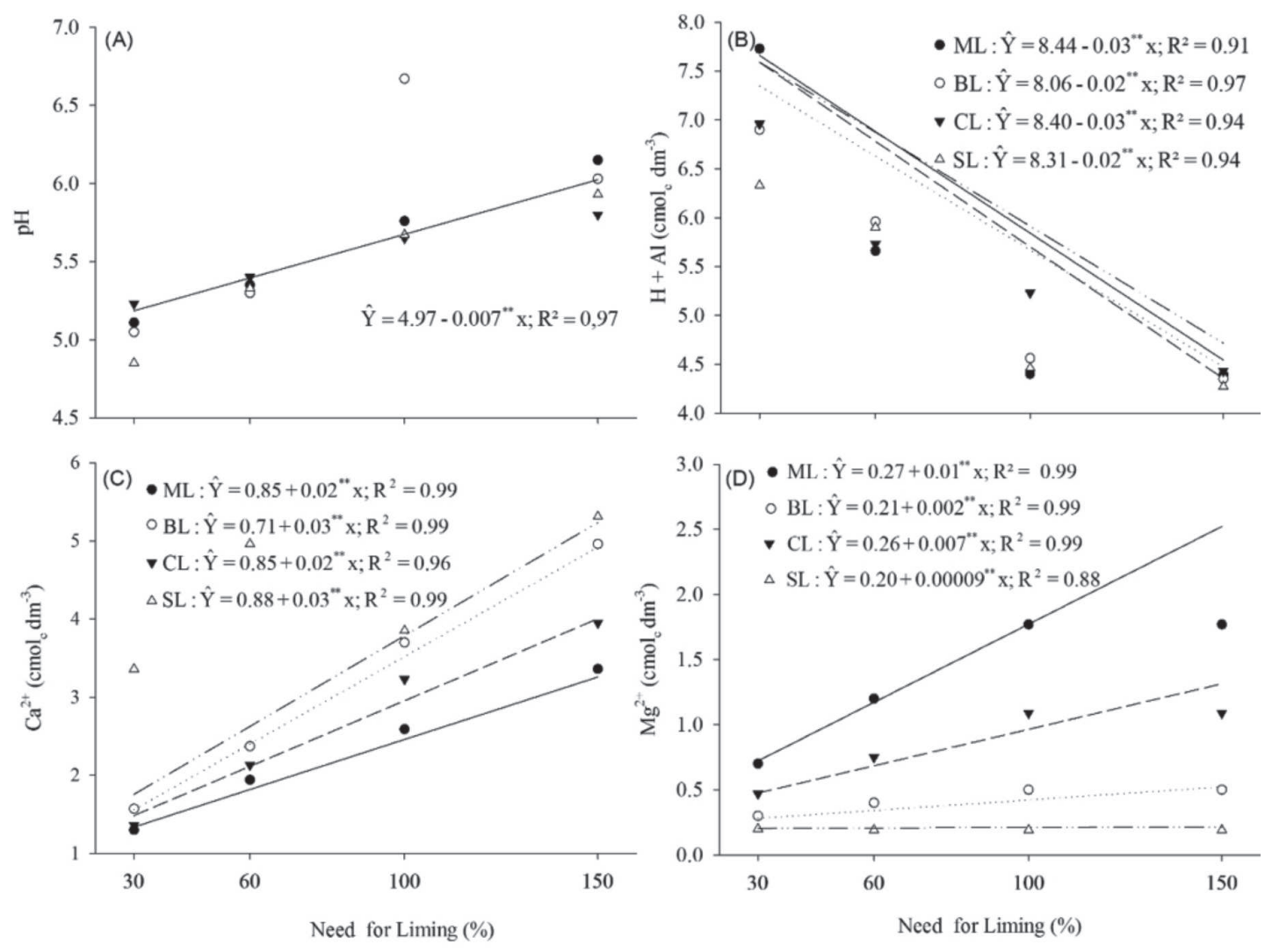

Figure 3: $\mathrm{pH}$ values in the soil as a function of liming requirement and $\mathrm{H}+\mathrm{Al}, \mathrm{Ca}^{2+}$, and $\mathrm{Mg}^{2+}$ in the soil as a function of different acidity correctives and the need for liming. $* *$ significant at the $1 \%$ probability level by the $t$ test. 
Table 3: Mean values of $\mathrm{pH}, \mathrm{H}+\mathrm{Al}, \mathrm{Ca}^{2+}$, and $\mathrm{Mg}^{2+}$ obtained for the samples of soils treated with different acidity correctives within different levels of liming 90 days after reaction

\begin{tabular}{|c|c|c|c|c|c|c|c|c|c|c|}
\hline \multirow{3}{*}{$\begin{array}{l}\text { Acidity } \\
\text { corrective }\end{array}$} & Test $^{1}$ & 30 & 60 & 100 & 150 & Test $^{1}$ & 30 & 60 & 100 & 150 \\
\hline & \multicolumn{5}{|c|}{ pH } & \multicolumn{5}{|c|}{$\mathbf{H}+\mathbf{A l}$} \\
\hline & \multicolumn{5}{|c|}{$\mathrm{cmol}_{\mathrm{c}} \mathbf{d m}^{-3}$} & & & & & \\
\hline $\mathrm{ML}$ & 4.61 & $5.11 \mathrm{a}^{*}$ & $5.35 \mathrm{a}^{*}$ & $5.76 \mathrm{a}^{*}$ & $6.15 \mathrm{a}^{*}$ & 9.03 & $7.73 \mathrm{a}^{*}$ & $5.66 d^{*}$ & $4.40 \mathrm{a}^{*}$ & $4.39 \mathrm{a}^{*}$ \\
\hline BL & 4.61 & $5.05 \mathrm{a}^{*}$ & $5.30 \mathrm{a}^{*}$ & $6.67 \mathrm{a}^{*}$ & $6.03 \mathrm{a}^{*}$ & 9.03 & $6.90 \mathrm{c}^{*}$ & $5.96 \mathrm{a}^{*}$ & $4.56 b^{*}$ & $4.35 \mathrm{a}^{*}$ \\
\hline $\mathrm{CL}$ & 4.61 & $5.23 \mathrm{a}^{*}$ & $5.40 \mathrm{a}^{*}$ & $5.65 \mathrm{a}^{*}$ & $5.80 \mathrm{a}^{*}$ & 9.03 & $6.96 b^{*}$ & $5.73 \mathrm{c}^{*}$ & $5.23 \mathrm{a}^{*}$ & $4.43 \mathrm{a}^{*}$ \\
\hline \multirow[t]{3}{*}{ SL } & 4.61 & $4.85 \mathrm{a}^{*}$ & $5.33 \mathrm{a}^{*}$ & $5.67 \mathrm{a}^{*}$ & $5.93 \mathrm{a}^{*}$ & 9.03 & $6.33 \mathrm{~d}^{*}$ & $5.90 b^{*}$ & $4.46 c^{*}$ & $4.27 \mathrm{a}^{*}$ \\
\hline & \multicolumn{5}{|c|}{$\mathrm{Ca}^{2+}$} & \multicolumn{5}{|c|}{$\mathrm{Mg}^{2+}$} \\
\hline & $\mathrm{mol}_{\mathrm{c}} \mathrm{dm}^{-3}$ & & $\mathrm{cmol}_{\mathrm{c}} \mathrm{dm}^{-}$ & & & & & & & \\
\hline$\overline{\mathrm{ML}}$ & 0.68 & $1.30 \mathrm{~b}^{*}$ & $1.94 c^{*}$ & $2.59 \mathrm{~d}^{*}$ & $3.36 d^{*}$ & 0.14 & $0.70 \mathrm{a}^{*}$ & $1.20 \mathrm{a}^{*}$ & $1.77 \mathrm{a}^{*}$ & $1.77 \mathrm{a}^{*}$ \\
\hline BL & 0.68 & $1.57 \mathrm{a}^{*}$ & $2.37 b^{*}$ & $3.70 b^{*}$ & $4.96 b^{*}$ & 0.14 & $0.30 \mathrm{a}^{*}$ & $0.40 \mathrm{ab}^{*}$ & $0.50 b^{*}$ & $0.50 b^{*}$ \\
\hline CL & 0.68 & $1.36 \mathrm{~b}^{*}$ & $2.13 \mathrm{c}^{*}$ & $3.23 \mathrm{c}^{*}$ & $3.85 c^{*}$ & 0.14 & $0.47 \mathrm{a}^{*}$ & $0.75 \mathrm{ab}^{*}$ & $1.09 \mathrm{ab}^{*}$ & $1.09 \mathrm{ab}^{*}$ \\
\hline SL & 0.68 & $1.72 \mathrm{a}^{*}$ & $2.71 \mathrm{a}^{*}$ & $3.95 \mathrm{a}^{*}$ & $5.31 \mathrm{a}^{*}$ & 0.14 & $0.20 \mathrm{a}$ & $0.19 b$ & $0.19 b$ & $0.19 \mathrm{~b}$ \\
\hline
\end{tabular}

1: Control.

Means followed by one same letter, at least, in the column are not different from each other by the 5\% probability level by the test of Tukey. Means followed by an asterisk in the row are not different from control at the $5 \%$ probability level by the test of Dunnett.

A linear increase occurred in the average content of $\mathrm{Mg}^{2+}$ in the soil as the liming requirement levels increased (Figure 3D). The $b_{1}$ values of the equations presented in this figure indicate that each unit of liming requirement applied to the soil causes an increase of $0.01,0.002,0.007$, and $0.00009 \mathrm{cmol}_{\mathrm{c}} \mathrm{dm}^{-3}$ of $\mathrm{Mg}^{2+}$ when the soils were incubated with ML, BL, CL, and SL. The largest contribution of $\mathrm{ML}$ and $\mathrm{CL}$ of $\mathrm{Mg}^{2+}$ was expected since, among the evaluated limestones, they were those with the largest percentages of $\mathrm{MgO}$.

For the variable $\mathrm{Mg}^{2+}$, it was observed that at the $30 \%$ NL level, no difference was found between the application of the different limestones. At the $60 \% \mathrm{NL}$ level, the application of ML, BL, or CL resulted in a higher $\mathrm{Mg}^{2+}$ input to the soil when compared with SL. At the levels of 100 and $150 \%$ NL, ML and CL contributed with the largest input of $\mathrm{Mg}^{2+}$ to the soil (Table 3).

Treatments that received limestone presented higher and statistically significant $(\mathrm{p}<0.05)$ average values of $\mathrm{Ca}^{2+}$ and $\mathrm{Mg}^{2+}$ levels than the control by Dunnett's test (Table 3 ), except for the variable $\mathrm{Mg}^{2+}$ in the soil that received $\mathrm{SL}$, a fact attributed to chemical characteristics of the rock that has been previously discussed.

Regarding the NL level of agronomic interest, the evaluated limestones increased the level of $\mathrm{Ca}^{2+}$ from very low $\left(0.41-1.20 \mathrm{cmol}_{\mathrm{c}} \mathrm{dm}^{-3}\right)$ to the good level $\left(2.41-4.00 \mathrm{cmol}_{\mathrm{c}}\right.$ $\left.\mathrm{dm}^{-3}\right)$. For $\mathrm{Mg}^{2+}$, although its level in the soil was very low (d" $0.15 \mathrm{cmol}_{c} \mathrm{dm}^{-3}$ ), the incubation with ML increased it to a very good level $\left(>1.50 \mathrm{cmol}_{\mathrm{c}} \mathrm{dm}^{-3}\right)$. Biological and commercial limestones were used for the good level (0.91$1.50 \mathrm{cmol}_{c} \mathrm{dm}^{-3}$ ), while SL increased it to $0.20 \mathrm{cmol}_{c} \mathrm{dm}^{-3}$, classified as low level of $\mathrm{Mg}^{2+}\left(0.16-0.45 \mathrm{cmol}_{\mathrm{c}} \mathrm{dm}^{-3}\right)$.
Limestones should be chosen not only for their acid neutralization power but mainly for the $\mathrm{Ca}: \mathrm{Mg}$ ratio in the material. Among the limestones of acidity under study, the Ca:Mg ratio was 3:1 for ML, 15:1 for BL, 4:1 for CL, and 114:1 for SL. Currently, most studies consider Ca:Mg ratios between 4:1 for most cultivated plants and 8:1 as adequate for some less-demanding plants (Medeiros et al., 2008). Excess of $\mathrm{Ca}^{2+}$ in relation to $\mathrm{Mg}^{2+}$ in the soil solution may impair the absorption of the later (Malavolta et al., 1997). The interrelationship between nutrients in plant nutrition is related to their close chemical properties, such as ionic radius, valence, degree of hydration, and mobility, causing competition for soil adsorption sites and root absorption (Medeiros et al., 2008; Júnior et al., 2013). Medeiros et al. (2008) observed the influence of the high $\mathrm{Ca}: \mathrm{Mg}$ ratio of the correctives on nutritional imbalance, through a reduction in the growth and productivity of forage plants.

\section{CONCLUSIONS}

When applied to soil, biogenic, metamorphic, and sedimentary limestones are able to correct the soil acidity. The increase in the levels of $\mathrm{Ca}^{2+}$ and $\mathrm{Mg}^{2+}$ in the soil are influenced by the chemical composition of the limestones. The limestones of sedimentary and metamorphic origin account for the greater concentration of $\mathrm{Ca}^{2+}$ and $\mathrm{Mg}^{2+}$ in the soil.

\section{REFERENCES}

Alleoni LRF, Cambri MA \& Caires EF (2005) Atributos químicos de um Latossolo de cerrado sob plantio direto, de acordo com doses e formas de aplicação de calcário. Revista Brasileira de Ciência do Solo, 29:923-934. 
Alvarez VVH, Dias LE, Ribeiro AC \& Souza RB (1999) Calagem. In: Ribeiro AC, Guimaraes PTG \& Alvarez VVH (Eds.) Recomendação para o uso de corretivos e fertilizantes em Minas Gerais. Viçosa, Comissão de Fertilidade do Solo do Estado de Minas Gerais. p.43-60.

Amaral Sobrinho NMB, Costa LM, Oliveira C \& Velloso ACX (1992) Metais pesados em alguns fertilizantes e corretivos. Revista Brasileira de Ciência do Solo, 16:271-276.

Bellingieri PA, Alcarde JC \& Souza ECA de (1989) Eficiência relativa de diferentes frações granulométricas de calcários na neutralização da acidez dos solos, avaliada em laboratório. Anais da Escola Superior de Agricultura Luiz de Queiroz, 46:303-317.

Bortoluzzi ED, Parize GL, Korchagin J, Silva VR, Rheinheimer DS \& Kamins J (2014) Soybean root growth and crop yield in reponse to liming at the beginning of a no-tillage system. Revista Brasileira de Ciência do Solo, 38:262-271.

Crusciol CAC, Artigiani ACCA, Arf O, Carmeis Filho ACA, Soratto RP, Nascente AS \& Alvarez RCF (2016) Soil fertility, plant nutrition, and grain yield of upland rice affected by surface application of lime, silicate, and phosphogypsum in a tropical no-till system. Catena, 137:87-99.

Dias GTM (2000) Granulados bioclásticos: Algas calcárias. Revista Brasileira de Geofísica, 18:307-318.

Embrapa - Empresa Brasileira de Pesquisa Agropecuária (2011) Manual de métodos de análises de solos. $2^{\mathrm{a}}$ ed. Rio de Janeiro, Embrapa Solos. 230p.

Embrapa - Empresa Brasileira de Pesquisa Agropecuária (2018) Sistema Brasileiro de Classificação de Solos. $5^{a}$ ed. Rio de Janeiro, Embrapa Solos. 180p.

Fageria NK (2011) Efeito da calagem na produção de arroz, feijão, milho e soja em solo de cerrado. Pesquisa Agropecuária Brasileira, 11:1419-1424.

Gallo JR \& Catani RA (1954) Solubilidade de alguns tipos de calcários. Bragantia, 13:63-74.

Gonçalves JRP, Moreira A, Büll LT, Crusciol CAC \& Villas Boas RL (2011) Granulometria e doses de calcário em diferentes sistemas de manejo. Acta Science Agronômica, 33:369-75.

Gregg SJ \& Sing KSW (1982) Adsorption, Surface area and Porosity. New York, Academic Press. 303p.

Grunwaldt HS, Zimina A, Göttlicher J, Steininger R \& Grunwaldt JD (2016) Study of the relation between Mg content and dissolution kinetics of natural lime stone using iXRF, iXRD and iXAS J. Journal of Physics Conference Series, 712:10.1088.

Guerra MBB, Neto EL, Prianti MTA, Pereira Filho ERP \& Schaefer CEGR (2013) Post-fire study of the Brazilian Scientific Antarctic Station: Toxic element contamination and potential mobility on the surrounding environment. Microchemical Journal, 110:21-27.

Jordt - Evangelista H \& Viana DJ (2000) Mármores da região de Itaoca (ES) e escarnitos no contato com diques máficos e félsicos: Mineralogia e petrogênese. Geonomos, 08:61-62.

Inagaki TM, de Moraes Sá JC, Caires EF \& Gonçalves DRP (2016) Lime and gypsum application increases biological activity, carbon pools, and agronomic productivity in highly weathered soil. Agriculture Ecosystems \& Environment, 231:156-165.
Kurihara CH, Maeda S, Hernani LC \& Silva WM (1999) Eficiência relativa de frações granulométricas de calcários Sul-MatoGrossenses. Pesquisa Agropecuária Brasileira, 34:1443-1449.

Júnior MPAG, Santos AC, Dos Santos Araújo A, Oliveira LBT, Rodriguês MOD \& Martins AD (2013) Relação Ca:Mg do corretivo da acidez do solo e as características agronômicas de plantas forrageiras. Revista Brasileira de Saúde e Produção Animal,14: 460-471.

Mapa - Ministério da Agricultura, Pecuária e Abastecimento (2014) Manual de métodos analíticos oficiais para fertilizantes minerais, orgânicos, organominerais e corretivos. Brasília, MAPA. $141 \mathrm{p}$.

Malavolta E, Vitti GC \& Oliveira AS (1997) Avaliação do estado nutricional de plantas: Princípios e aplicações. Piracicaba, Potafos. 308p.

Medeiros JC, Albuquerque JÁ, Mafra AL, Rosa JD \& Gatiboni LC (2008) Relação cálcio:magnésio do corretivo da acidez do solo na nutrição e no desenvolvimento inicial de plantas de milho em um Cambissolo Húmico Álico. Semina: Ciências Agrárias, 29:799-806.

Melo TV \& Moura AMA (2009) Utilização da farinha de algas calcáreas na alimentação animal. Revista Archivos de Zootecnia, 58:99-107.

Rodrighero MB, Barth G \& Caires EF (2015) Aplicação superficial de calcário com diferentes teores de magnésio e granulometrias em sistema plantio direto. Revista Brasileira de Ciência do Solo, 39:1723-1736.

Ribeiro AC, Guimaraes PTG \& Alvarez VVH (1999) Recomendação para o uso de corretivos e fertilizantes em Minas Gerais. $5^{\text {a }}$ ed. Viçosa, Comissão de Fertilidade do Solo do Estado de Minas Gerais. 359p.

Rheinheimer DS, Tiecher T, Gonzatto R, Zafar M \& Brunetto G (2018) Residual effect of surface-applied lime on soil acidity properties in a long-term experiment under no-till in a Southern Brazilian sandy Ultisol. Geoderma, 313:07-16.

Pansu M \& Gautheyrou J (2003) L'analyse du sol minéralogique, organique et minérale. Springer, France. 993p.

Quaggio JA (2000) Acidez e calagem em solos tropicais. Campinas, Instituto Agronômico. 111p.

Universidade Federal de Viçosa (2007) SAEG: Sistema para Análises Estatísticas e Genéticas. Versão 9.1. Viçosa, Fundação Arthur Bernardes. CD-ROM.

Sampaio JA \& Almeida SLM (2008) Calcário e dolomito. In: Luz $\mathrm{AB}$ da \& Lins AF (Eds) Rochas e Minerais Industriais: Usos e Especificações. Rio de Janeiro, CETEM/MCTI. p.363-387.

Singh SDK, Tripathi SSS, Sharma NK, Dubey DK \& Chauhan MV (2017) Toxicity of aluminium on various levels of plant cells and organism: a review. Environmental and Experimental Botany, 137:177-193.

Sousa DMG De, Miranda LN De \& Oliveira ESA De (2007) Acidez do solo e sua correção. In: Novais RF, Alvarez VVH, Barras de NF, Fontes RL, Cantarutti RB \& Lima JC (Eds) Fertilidade do Solo. Viçosa, SBCS. p.206-262. 